\title{
ESTIMATION OF MICROCLIMATE CONDITIONS AT LONGWALL EXCAVATIONS IN HARD COAL MINES
}

\section{Introduction}

The depletion of shallow deposits in underground mines results in a systematic increase in mining depth, at the same time leading to a greater intensity of natural hazards [1]. Virgin rock temperature increases along with the depth which has an inevitable influence on the microclimate of the work places. The negative influence of microclimate conditions is mainly caused by high coal output concentration, increased power to underground extraction machinery and haulage equipment as well as high air humidity in excavation areas. In the near future it may be necessary to mine in rock masses with a temperature of $50^{\circ} \mathrm{C}$ where climate threat will be the main decisive element regarding the safety of miners, and this factor could even affect the possibility of extracting coal effectively at depth.

Hard microclimate conditions not only decrease efficiency, but more alarmingly, such conditions can endanger the health and even the lives of the workers themselves due to overheating of the human organism. Obtaining thermal equilibrium happens as a result of body thermoregulation. The body can detect changes in its surrounding temperature as well as its inner temperature thanks to thermo receptors located in different parts of the body, mainly in skin. High temperature surroundings cause physiological reactions to occur, such as dilating blood vessels of skin, increasing blood flow to the body surface and sweat secretion through sweat glands on the skin.

Individual psychophysical factors, such as age, body structure, general health condition, acclimatization, mental immunity and personal predispositions also have a great impact on the human organism's reaction to hard climate conditions in hot surroundings. At about $30^{\circ} \mathrm{C}$ in relatively high humidity, people with limited thermal tolerance, are already prone to heat exhaustion or overheating, particularly during a great physical effort $[2,3]$. These tough climate conditions can be observed at longwall mine excavations.

\footnotetext{
* AGH University of Science and Technology, Krakow; szlazak@agh.edu.pl; obracaj@agh.edu.pl;
} bgluch@agh.edu.pl 
This paper aims at estimating microclimate conditions on the basis of research conducted in hard coal mines. On the basis of the results obtained, microclimates at longwall mine excavations can be estimated, taking into consideration well-known heat indexes.

\section{Methodology of microclimate measurements at longwall mine excavations}

Determining a suitable methodology of research is of key significance when conducting an analysis, based on real changes in microclimate conditions, in a longwall mine excavations. It was necessary to measure the climatic parameters at the headgate and tailgate of a longwall mine to obtain a complete set of results. In underground mine workings, the most important parameters include: temperature, measured by a dry thermometer $t_{s}$, temperature measured by a wet thermometer $t_{m}$, relative humidity $\varphi$ and airflow rate $v$ at the longwall. Measurements were taken at sampling stations at underground excavations in 5 hard coal mines at 22 longwalls. The longwalls were mined at depths from 650 to $1070 \mathrm{~m}$ and were ventilated by $\mathrm{U}$ and $\mathrm{Y}$ ventilation systems.

Figure 1 presents measurement schemes of air parameters. The $\mathrm{U}$ ventilation system is used most frequently in Polish hard coal mines, however, this system's disadvantage is poor operation in unfavorable climate conditions [4]. In longwall excavations ventilated by the $U$ system, measurements were taken at the head entrance, about $10 \mathrm{~m}$ before the gate to the longwall, as well as in a tail entrance, no more than $10 \mathrm{~m}$ behind the tail gate (Fig. 1a). In longwall excavations ventilated by the $\mathrm{Y}$ system the measurements were taken in the entrance about $10 \mathrm{~m}$ before the headgate as well as in an entry with return air along goaf at no more than $10 \mathrm{~m}$ behind the tailgate (Fig. 1a). The latter system is more favorable during temperature hazard [4]. Sampling stations reflect work places in headgates and tailgates.

a)

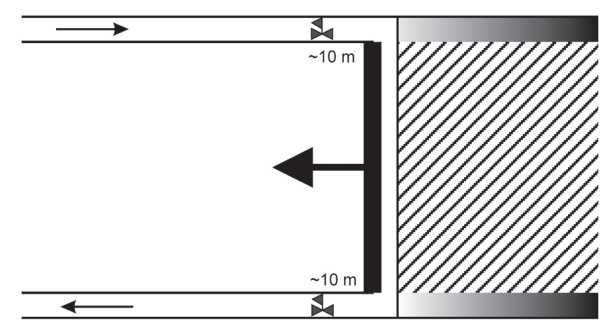

b)

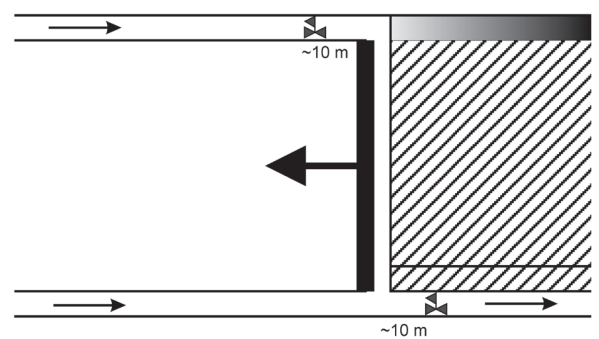

Fig. 1. Scheme of ventilating a longwall with: a) U ventilation system; b) Y ventilation systems 


\section{Results of microclimate measurements}

The results of conducted measurements are presented in Table 1.

TABLE 1

Data sheet from measurements in longwalls

\begin{tabular}{|c|c|c|c|c|c|c|c|c|c|c|}
\hline \multirow{2}{*}{ Mine } & \multirow{2}{*}{ Longwall } & \multirow{2}{*}{$\begin{array}{c}\text { Ventilation system / } \\
\text { air cooling }\end{array}$} & \multicolumn{4}{|c|}{ Headgate } & \multicolumn{4}{|c|}{ Tailgate } \\
\hline & & & $t_{s},\left[{ }^{\circ} \mathrm{C}\right]$ & $t_{m},\left[{ }^{\circ} \mathrm{C}\right]$ & $\varphi,[\%]$ & $v,[\mathrm{~m} / \mathrm{s}]$ & $t_{s},\left[{ }^{\circ} \mathrm{C}\right]$ & $t_{m},\left[{ }^{\circ} \mathbf{C}\right]$ & $\varphi,[\%]$ & $v,[\mathrm{~m} / \mathrm{s}]$ \\
\hline \multirow{10}{*}{ B-Z } & \multirow{2}{*}{1} & \multirow{2}{*}{$\mathrm{U} /$ air cooling } & 23.2 & 19.0 & 67 & 1.33 & 26.8 & 24.0 & 79 & 1.60 \\
\hline & & & 24.0 & 21.8 & 83 & 1.95 & 29.8 & 28.4 & 90 & 2.30 \\
\hline & \multirow{2}{*}{2} & \multirow{2}{*}{$\mathrm{U} /$ air cooling } & 22.6 & 18.0 & 64 & 0.97 & 27.0 & 25.0 & 85 & 1.15 \\
\hline & & & 21.0 & 16.8 & 66 & 1.05 & 25.8 & 22.8 & 78 & 1.27 \\
\hline & \multirow{2}{*}{3} & \multirow{2}{*}{ Y / air cooling } & 24.0 & 20.0 & 69 & 1.05 & 28.4 & 25.8 & 81 & 2.33 \\
\hline & & & 24.4 & 20.4 & 70 & 1.12 & 26.0 & 22.4 & 73 & 2.60 \\
\hline & \multirow{2}{*}{4} & \multirow{2}{*}{$\mathrm{U} /$ air cooling } & 22.8 & 18.2 & 64 & 0.87 & 29.0 & 24.0 & 66 & 0.90 \\
\hline & & & 21.6 & 17.8 & 69 & 1.53 & 27.2 & 25.6 & 88 & 2.38 \\
\hline & \multirow{2}{*}{5} & \multirow{2}{*}{ Y / air cooling } & 26.0 & 22.0 & 71 & 1.25 & 31.0 & 28.8 & 85 & 1.58 \\
\hline & & & 25.0 & 21.4 & 73 & 1.33 & 26.6 & 26.6 & 86 & 1.73 \\
\hline \multirow{6}{*}{$P$} & 6 & Y / air cooling & 18.2 & 14.2 & 63 & 2.40 & 25.2 & 21.2 & 69 & 2.30 \\
\hline & 7 & Y / air cooling & 18.2 & 15.4 & 74 & 2.15 & 24.2 & 21.8 & 81 & 6.25 \\
\hline & 8 & Y / air cooling & 22.4 & 17.0 & 57 & 5.90 & 31.4 & 28.2 & 78 & 2.03 \\
\hline & 9 & Y / air cooling & 20.8 & 18.0 & 76 & 1.70 & 28.4 & 26.2 & 84 & 2.10 \\
\hline & 10 & Y / air cooling & 23.0 & 19.6 & 72 & 1.30 & 31.2 & 27.8 & 77 & 1.20 \\
\hline & 11 & Y / air cooling & 22.2 & 20.0 & 81 & 0.78 & 25.6 & 23.8 & 86 & 1.11 \\
\hline \multirow{4}{*}{$\mathrm{J}-\mathrm{M}$} & 12 & $\mathrm{U} /$ air cooling & 22.4 & 18.8 & 70 & 1.16 & 28.2 & 26.8 & 89 & 1.15 \\
\hline & 13 & $\mathrm{U} /$ air cooling & 27.8 & 26.0 & 86 & 1.09 & 31.8 & 30.6 & 92 & 1.03 \\
\hline & 14 & $\mathrm{Y} /$ air cooling & 23.6 & 17.4 & 52 & 3.81 & 31.2 & 28.6 & 82 & 4.39 \\
\hline & 15 & U / air cooling & 22.2 & 19.4 & 76 & 1.25 & 31.4 & 27.8 & 75 & 1.43 \\
\hline \multirow{3}{*}{ B } & 16 & Y / air cooling & 18.4 & 16.0 & 77 & 2.45 & 26.6 & 24.2 & 82 & 2.45 \\
\hline & 17 & Y / air cooling & 19.8 & 17.2 & 77 & 2.18 & 25.6 & 23.4 & 83 & 2.18 \\
\hline & 18 & $\mathrm{Y} /$ air cooling & 20.2 & 17.8 & 79 & 1.98 & 26.6 & 24.4 & 83 & 1.98 \\
\hline \multirow{4}{*}{$\mathrm{K}$} & 19 & U / without cooling & 19.2 & 16.2 & 73 & 3.75 & 20.4 & 19.0 & 88 & 3.67 \\
\hline & 20 & U / air cooling & 24.4 & 20.6 & 70 & 2.52 & 27.8 & 25.6 & 84 & 2.58 \\
\hline & 21 & $\mathrm{U} /$ air cooling & 17.4 & 14.0 & 68 & 3.19 & 23.4 & 20.6 & 77 & 3.20 \\
\hline & 22 & $\mathrm{U} /$ air cooling & 24.0 & 21.6 & 81 & 3.24 & 23.6 & 23.0 & 95 & 2.94 \\
\hline \multicolumn{3}{|c|}{ Average values } & 22.2 & 18.7 & 71.4 & 2.00 & 27.4 & 25.1 & 82.1 & 2.20 \\
\hline \multicolumn{3}{|c|}{ Standard deviation } & 2.6 & 2.6 & 7.7 & 1.20 & 2.9 & 2.8 & 6.7 & 1.2 \\
\hline
\end{tabular}

Volumetric air streams in the intake airways ranged from 600 to $1640 \mathrm{~m}^{3} / \mathrm{min}$. In longwall excavations with a $\mathrm{Y}$ ventilation system, the participation of air in the face ranged from $40.3 \%$ to $82.4 \%$ of total intake air. Air cooling was used to improve climate conditions due to the depth of mining in longwalls. 


\section{Microclimate indexes at longwall excavations under research}

The value of basic air parameters and microclimate indexes, which take into consideration the joint influence of a few basic air parameters were used to determine microclimate. The best-known microclimate indexes include: relative index of air cooling power $K_{w}$ [5], equivalent French temperature TFR [6], equivalent temperature of climate $t_{z k}$ [7], wet-bulb globe temperature index [8]. Table 2 presents the definitions of heat indexes and methods for their determination. On the basis of those indexes, microclimate conditions in excavations were estimated.

\section{TABLE 2}

\section{Microclimate indexes}

\begin{tabular}{|c|c|c|c|c|c|}
\hline Index & Symbol & Unit & $\begin{array}{l}\text { Determination } \\
\text { method }\end{array}$ & Remarks & $\begin{array}{l}\text { Explanations for } \\
\text { equations }\end{array}$ \\
\hline $\begin{array}{c}\text { Relative index } \\
\text { of air cooling } \\
\text { power } K_{w}\end{array}$ & $K_{w}$ & $\begin{array}{l}\text { Wet } \\
\text { Kata }\end{array}$ & $\begin{array}{c}\text { measurement by wet } \\
\text { katatermometer }\end{array}$ & $K_{w}<11$ Wet Kata part-time work & \multirow{4}{*}{$\begin{array}{l}t_{m}-\text { temperature } \\
\text { measured by wet } \\
\text { thermometer }\left[{ }^{\circ} \mathrm{C}\right], \\
t_{s}-\text { temperature } \\
\text { measured by dry } \\
\text { thermometer }\left[{ }^{\circ} \mathrm{C}\right], \\
v-\text { air velocity }[\mathrm{m} / \mathrm{s}]\end{array}$} \\
\hline $\begin{array}{l}\text { Equivalent } \\
\text { French } \\
\text { temperature } \\
\text { TFR }\end{array}$ & $T F R$ & ${ }^{\circ} \mathrm{C}$ & $T F R=0.7 t_{m}+0.3 t_{s}-v$ & $\begin{aligned}- & T F R \leq 28^{\circ} \mathrm{C}-\text { normal work } \\
& \text { conditions, } \\
- & T F R \text { ranging from } 28 \text { to } 34^{\circ} \mathrm{C}- \\
& \text { work harmful to health, } \\
- & T F R>34^{\circ} \mathrm{C}-\text { dangerous work } \\
& \text { conditions }\end{aligned}$ & \\
\hline $\begin{array}{l}\text { Equivalent } \\
\text { temperature of } \\
\text { climate } t_{z k}\end{array}$ & $t_{z k}$ & ${ }^{\circ} \mathrm{C}$ & $t_{z k}=0.6 t_{m}+0.4 t_{s}-v$ & 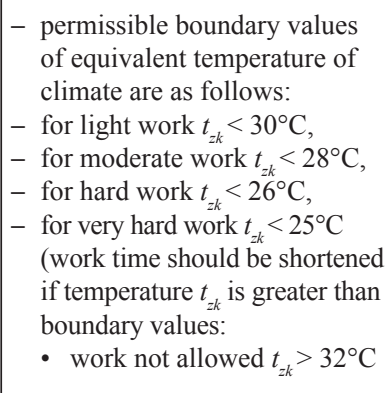 & \\
\hline $\begin{array}{c}\text { Wet-bulb } \\
\text { globe } \\
\text { temperature } \\
\text { index }(W B G T)\end{array}$ & $W B G T$ & ${ }^{\circ} \mathrm{C}$ & $\begin{array}{c}W B G T= \\
0.67 t_{m}+0.33 t_{s}\end{array}$ & Norm PN-EN 272443:2005 & \\
\hline
\end{tabular}

The measurements obtained determined the microclimate indexes. On the basis of the calculations carried out it can be concluded that the microclimate parameters were as follows: - at headgate:

- relative index of air cooling power ranged from 12.9 to 41.1 Wet Kata (on average it was 24.7 Wet Kata, but in no case was it lower than 11 Wet Kata),

- equivalent French temperature ranged from 11.8 to $25.5^{\circ} \mathrm{C}$ (on average it was $17,8^{\circ} \mathrm{C}$ ), 
- equivalent temperature of climate ranged from 12.2 to $26.6^{\circ} \mathrm{C}$ (on average it was $\left.18.1^{\circ} \mathrm{C}\right)$

- wet-bulb globe temperature index ranged from 15.1 to $26.6^{\circ} \mathrm{C}$ (on average it was $\left.19.8^{\circ} \mathrm{C}\right)$

- at tailgate:

- relative index of air cooling power ranged from 7.1 to 31.4 Wet Kata (on average it was 17.2 Wet Kata and in one case it was lower than 11 Wet Kata),

- equivalent French temperature ranged from 15.8 to $29.9^{\circ} \mathrm{C}$ (on average it was $23.5^{\circ} \mathrm{C}$ ),

- equivalent temperature of climate ranged from 15.9 to $30.1^{\circ} \mathrm{C}$ (on average it was $23.8^{\circ} \mathrm{C}$ ),

- wet-bulb globe temperature index ranged from 19.5 to $31.0^{\circ} \mathrm{C}$ (on average it was $\left.25.8^{\circ} \mathrm{C}\right)$.

Figures 2-4 present changes in indexes in the function of air temperature measured by a dry thermometer.

a)

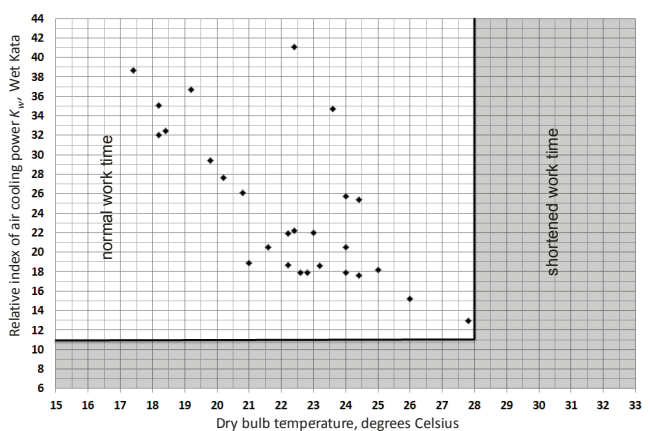

b)

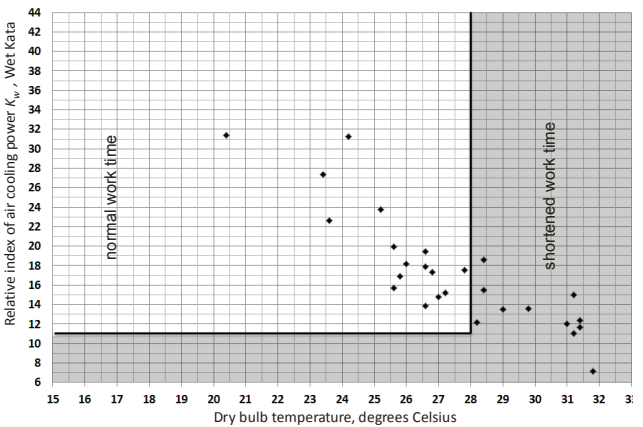

Fig. 2. Relative index of air cooling power $K_{w}$ as a function of air temperature: a) the headgate of the longwalls; b) the tailgate of the longwalls

a)

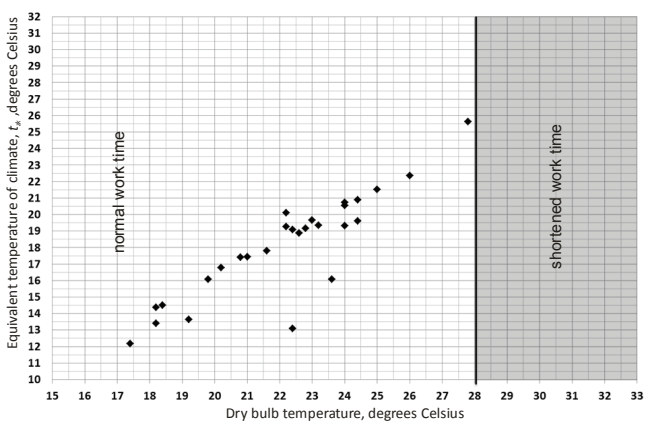

b)

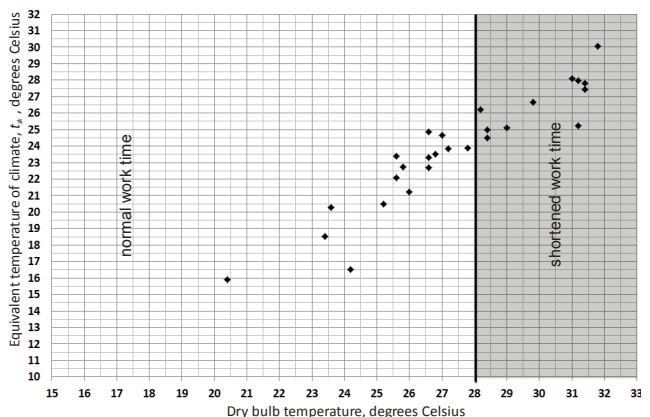

Fig. 3. Equivalent temperature of climate $t_{z k}$ as a function of air temperature:

a) headgates; b) tailgates 
a)

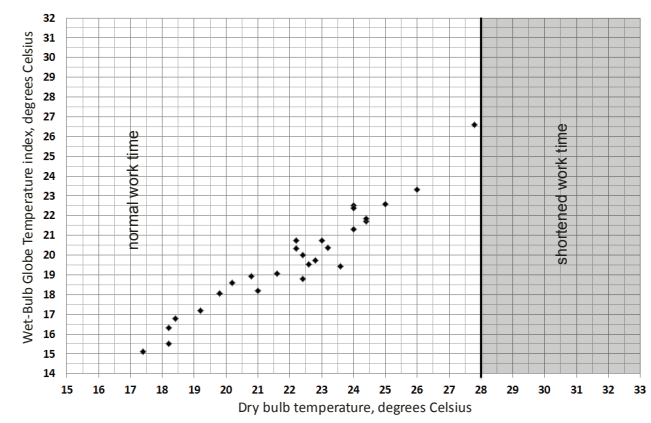

b)

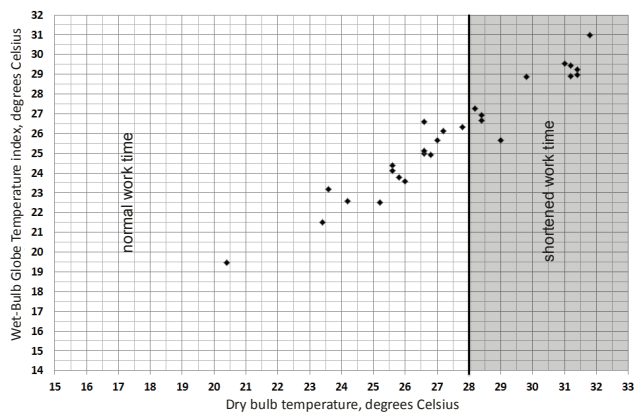

Fig. 4. Wet Bulb Globe Temperature Indicator $W B G T$ as a function of air temperature:

a) the headgate of the longwalls; b) the tailgate of the longwalls

Mining regulations requirements [9] for air parameters at the headgate of longwalls were not exceeded; therefore there was no shortened work time. Air cooling in the longwall excavation was sufficient to maintain required parameters. At the outlet from longwall excavation, permissible air parameters were exceeded in 11 cases, the first of which being taken on a dry thermometer. In each case air cooling was used. People working in such conditions worked in short stints. These indexes indicate hard working conditions at a longwall excavation outlet. However, it must be emphasized that for miners working there, microclimate conditions are connected not only with air parameters, but also with the nature of the work, the thermal insulation of the miners clothing and their acclimatization to the given conditions. These are the deciding factors associated with heat stress. Heat comfort indicators and the factors mentioned above should be used to estimate microclimate conditions.

\section{Estimation of thermal comfort in longwalls under research}

Thermal comfort is a state in which a man does not feel either cold or heat [10]. Clothing is one of the main elements which should ensure a man's thermal comfort in various thermal environments at different levels of physical activity. As far as thermal comfort is concerned, the human organism's thermal equilibrium is balanced. To estimate thermal comfort, different indexes (criteria) of estimating thermal work conditions need to be applied, none of which are currently obligatory in Polish hard coal mines.

Results were used and calculations made using the following two indexes: American effective temperature $A T E$ and thermal discomfort indicator. The explanations for these indexes can be found in Table 3 .

American effective temperature is one of the indexes used for determining microclimates in the work place. American effective temperature is used to determine climate norms and is currently used, among others, in the American and German mining industries. Nomograms for the varying thermal insulation of clothing can be found in literature $[6,9]$. As there was no data concerning thermo insulation of workers of longwall excavations under research, 
the ATE index was calculated on the assumption that the thermo insulation of a workers' clothing was 1 clo (miner's normal work clothing [10]) and 0 clo (unclothed workers). Figure 5 presents a graphic interpretation of the changes in the ATE index, the temperature being measured using a dry thermometer.

TABLE 3

Microclimate index $A T E$ and indicator $\delta$

\begin{tabular}{|c|c|c|c|c|}
\hline Index & Symbol & Unit & $\begin{array}{l}\text { Determination } \\
\text { method }\end{array}$ & Remarks \\
\hline $\begin{array}{c}\text { American } \\
\text { effective } \\
\text { tempera- } \\
\text { ture [6] }\end{array}$ & $A T E$ & ${ }^{\circ} \mathrm{C}$ & $\begin{array}{l}\text { read from } \\
\text { nomograms }\end{array}$ & $\begin{array}{l}\text { According to German norm: } \\
A T E<25^{\circ} \mathrm{C} \text { or } t_{s}<28^{\circ} \mathrm{C}-\text { normal work time, } \\
A T E>25^{\circ} \mathrm{C} \text { and } A T E<30^{\circ} \mathrm{C} \text { or } t_{s}>28 \text { - short- } \\
\text { ened work time, } \\
A T E>32^{\circ} \mathrm{C} \text { - work not allowed }\end{array}$ \\
\hline $\begin{array}{c}\text { Thermal } \\
\text { discomfort } \\
\text { indicator } \\
{[6]}\end{array}$ & $\delta$ & - & $\begin{array}{l}\text { read from } \\
\text { nomograms }\end{array}$ & $\begin{array}{l}\delta<0 \text { cool environment, } \\
\delta=0 \text { thermal comfort, } \\
0<\delta<0.2 \text { - favourable climatic conditions, } \\
0.2 \leq \delta<0.5 \text { - satisfactory climatic conditions, } \\
0.5 \leq \delta<0.8 \text { - hard climatic conditions, } \\
0.8 \leq \delta<1-\text { very hard climatic conditions, } \\
\delta \geq 1-\text { discomfort hazardous to health }\end{array}$ \\
\hline
\end{tabular}

The results were compared to ATE permissible values according to German regulations. The values obtained were compared to $N D N$ value used in the German mining industry. According to these regulations [6] if $A T E$ remains in the range between $25-30^{\circ} \mathrm{C}$ and at the same time the dry temperature is above $28^{\circ} \mathrm{C}$, a German miners' work time should be shortened and if $A T E$ is greater than $30^{\circ} \mathrm{C}$ work is not allowed. When comparing data in Figures 2-4 to data in Figure 5 it can be concluded that thermal working conditions were unfavorable at the outlet from longwalls, at the points were the test measurements were taken.

a)

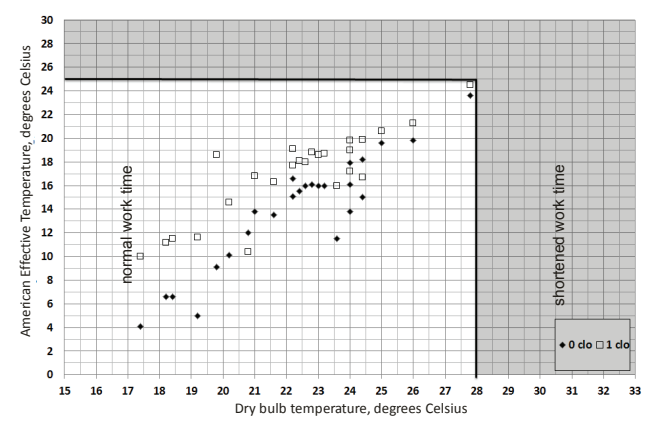

b)

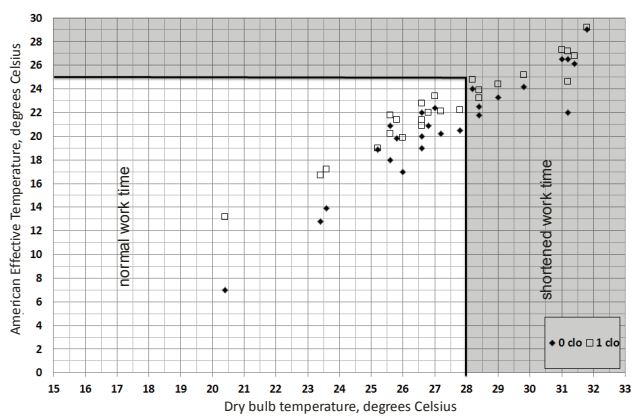

Fig. 5. American effective temperature $A T E$ as a function of air temperature (thermal insulation of clothing 0 and 1 clo): a) the headgate of the longwalls; b) the tailgate of the longwalls 
Conditions of thermal comfort for workers can also be determined by a thermal discomfort indicator $\delta[6]$. This indicator not only helps to estimate work climate conditions, but also to analyze the influence of microclimate parameters, clothing and metabolic rate according to conditions in the work environment. If indicator $\delta$ is equal or greater than unit, work in a given environment should not be allowed due to a worker's heat stress or heat stroke [6].

To calculate indicator $\delta$ it was assumed that workers at longwall excavations wear protective clothing with an insulation of 1 clo or 0 clo at tailgate. Calculations were carried out for both acclimatized and non-acclimatized workers for three different values of metabolic rate: 100,165 and $230 \mathrm{~W} / \mathrm{m}^{2}$. Nomograms for air relative humidity of $60 \%, 80 \%$, $100 \%$ were used for calculations [11].

Figures $6 \mathrm{e}, \mathrm{f}$ present an interpretation of the thermal discomfort indicator in the function of temperature measured by a dry thermometer for acclimatized workers wearing insulated clothing of 1 clo or 0 clo while Figures $6 \mathrm{e}, \mathrm{f}$ for non-acclimatized workers wearing insulated clothing of 1 clo.

On the basis of the Figures it can be concluded that the harder a miner works (in clothing with 1 clo thermo insulation) the more exposed to the negative influence of microclimate parameters he is. Non-acclimatized workers find climatic conditions much worse. When acclimatized and non-acclimatized workers at the headgate and tailgate from longwall excavations were compared, there were more cases when $\delta$ indicator exceeded a boundary value, in other words, where thermal discomfort is hazardous to health $(\delta>1)$.

Thermo insulation of clothing has a great impact on the values of a thermal discomfort indicator. When comparing the results of the determined indicator for different thermo insulations for workers at tailgates and those working at longwall excavations it can be concluded that climate conditions for thermo insulation of clothing with 1 clo could be much better. When tests were carried out, acclimatized miners working hard in clothing would have suffered discomfort hazardous to health in 11 cases, and for clothing with thermo insulation of 0 clo with the same parameters would have been breached in only one case.

Taking former assumptions into consideration, Figure 7 presents the percentage distribution of thermal discomfort for moderate work $\left(M_{s r}=165 \mathrm{~W} / \mathrm{m}^{2}\right)$. It can be observed that at the headgate of the longwall excavation, hard climate conditions $(0.5 \leq \delta<0.8)$ prevail. In such thermal conditions when the thermo insulation co-efficient is 1 clo, a worker will generally feel uncomfortable. At the tailgates hard or very hard climate conditions prevail. For $26 \%$ of work places at the tailgate, climate conditions would be described as too warm if the thermal resistance of clothing was 1 clo with metabolic rate $M_{s r}=165 \mathrm{~W} / \mathrm{m}^{2}$. In such conditions the level of discomfort is described as hazardous to health [6].

Indexes proved that it is necessary to improve climate conditions by using available methods of controlling climate hazards. Air-conditioning systems used in longwalls did not have a beneficial effect for miners working at the tailgate. To improve work conditions, thermo insulation of clothing should be as little as possible, and workers should be acclimatized. 


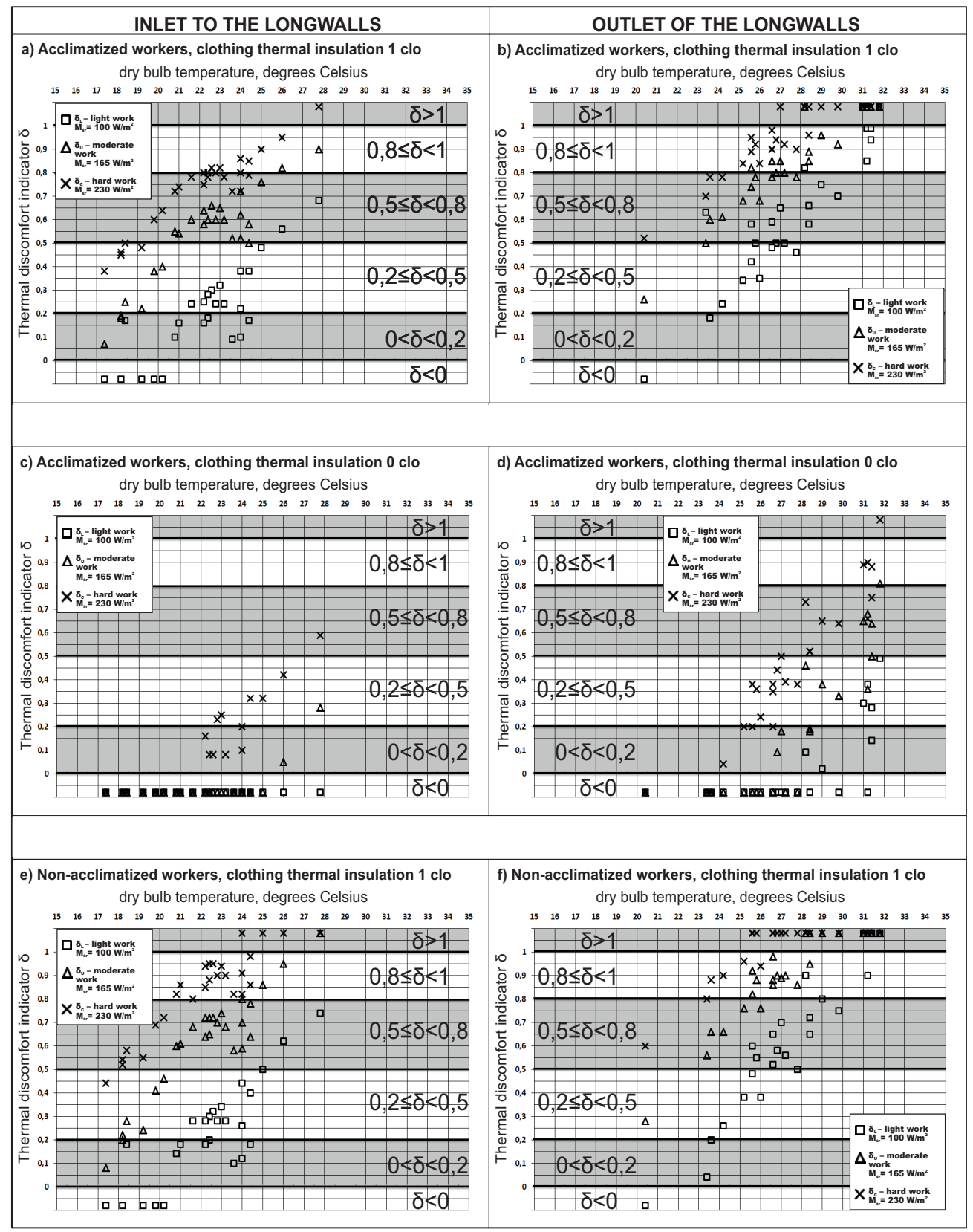

Fig. 6. Thermal discomfort indicator $\delta$ as a function of air temperature for: variable metabolic rate of worker, non-acclimatized and acclimatized workers, thermal insulation of clothing 0 and 1 clo $(\mathrm{a}, \mathrm{c}, \mathrm{e})$ the headgate of the longwalls $(b, d, f)$ the tailgate of the longwalls 
a)

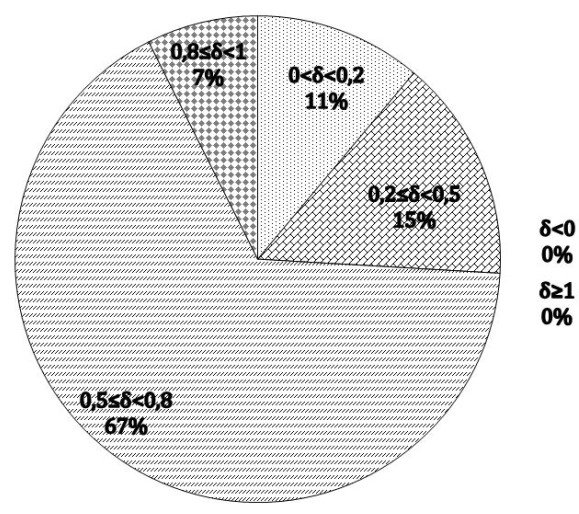

b)

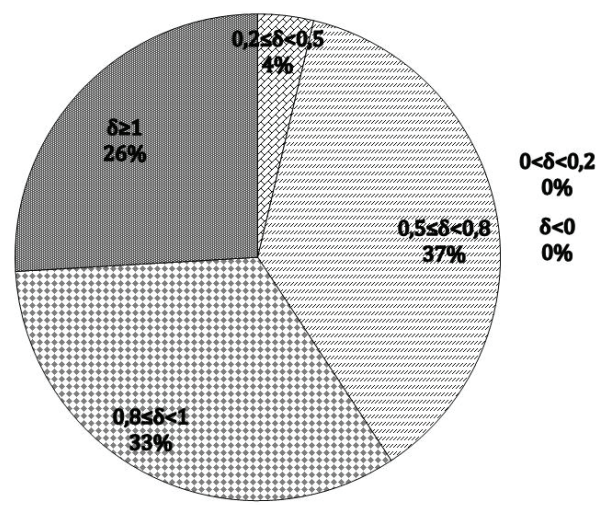

Fig. 7. Percentage distribution of thermal discomfort indicator for acclimatized workers, thermal insulation of clothing 1 clo and moderate work: a) the headgate of longwalls;

b) the tailgate of the longwalls

Degrees of climate hazard were determined on the basis of the thermal discomfort indicator [11]. Putting climatic conditions into a given degree consists in determining a value of indicator $\delta$ and classifying it according to the following conditions:

- ZKG-I $-1^{\text {st }}$ degree of climate hazard $\left(\delta_{C}>1, \delta_{U}<1, \delta_{L}<1\right)$; in environments belonging to 1 st degree of climate hazard work can be conducted in a shortened, six-hour work time with frequent or continuous control of thermal discomfort indicator,

- ZKG-II $-2^{\text {nd }}$ degree of climate hazard $\left(\delta_{U}>1, \delta_{L}<1\right)$, in environments belonging to 2nd degree of climate hazard work can be conducted in a shortened, six-hour work time including a planned relaxation break every hour of a work day,

- ZKG-III $-3^{\text {rd }}$ degree of climate hazard $\left(\delta_{L}>1\right)$, in environments belonging to the third degree of climate hazard, work should not be allowed, except for rescue operations.

In order to conduct the classification of degrees of climate hazards, it was assumed that workers were acclimatized, wore clothing with a thermo insulation of 0 clo or 1 clo and worked at the tailgate of the longwall. Table 4 presents classifications of longwalls according to work time or degrees of climate hazard (the tailgate of the longwall). When comparing microclimate indexes, it can be concluded that both the French temperature and equivalent temperature of climate are least restrictive. According to those indexes normal work time can be applied for most of the longwalls under research. However, Polish regulations, American effective temperature and degrees of climate hazard (1 clo) are stricter as more longwalls are classified as requiring a shortened work time. The main difference is the consideration given to the thermo insulation of clothing and how hard work is. The differences appear in environments where there is high temperature and humidity. The two tailgates from the longwalls were classified as $3^{\text {rd }}$ degree climate hazards, where work should be forbidden. Norms were exceeded for acclimatized people wearing clothing with thermo insulation of 1 clo. Reducing the thermo insulation of clothing to 0 clo results in reducing the degree of climate hazard. 
TABLE 4

Classification of excavations according to work time or climate hazard degrees (at the tailgate of longwalls)

\begin{tabular}{|c|c|c|c|c|c|c|c|c|c|}
\hline \multirow{3}{*}{$\begin{array}{c}\text { Work } \\
\text { time / } \\
\text { work for- } \\
\text { bidden }\end{array}$} & \multirow{3}{*}{$\begin{array}{c}\text { Polish } \\
\text { regula- } \\
\text { tions, } \\
{[\%]}\end{array}$} & \multirow{3}{*}{$\begin{array}{l}\text { French } \\
\text { tempera- } \\
\text { ture, [\%] }\end{array}$} & \multirow{2}{*}{\multicolumn{2}{|c|}{$\begin{array}{c}\text { Climate } \\
\text { equivalent } \\
\text { temperature, }[\%]\end{array}$}} & \multirow{2}{*}{\multicolumn{2}{|c|}{ 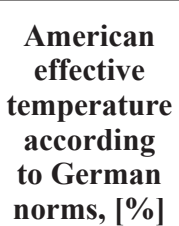 }} & \multicolumn{3}{|c|}{$\begin{array}{c}\text { Miners' climate hazard } \\
\text { degrees }\end{array}$} \\
\hline & & & & & & & \multirow[t]{2}{*}{ hazard degree } & \multicolumn{2}{|c|}{$\begin{array}{c}\text { acclimatized } \\
\text { workers, [\%] }\end{array}$} \\
\hline & & & $\begin{array}{l}\text { moderate } \\
\text { work }\end{array}$ & $\begin{array}{l}\text { hard } \\
\text { work }\end{array}$ & 1 clo & 0 clo & & 0 clo & 1 clo \\
\hline Forbidden & 0 & 0 & 0 & 0 & 0 & 0 & ZKG-III & 0 & 7.4 \\
\hline \multirow{2}{*}{ Shortened } & \multirow{2}{*}{40.7} & \multirow{2}{*}{3.7} & \multirow{2}{*}{11.1} & \multirow{2}{*}{22.2} & \multirow{2}{*}{40.7} & \multirow{2}{*}{40.7} & ZKG-II & 0 & 18.5 \\
\hline & & & & & & & ZKG-I & 3.7 & 14.8 \\
\hline Normal & 59.3 & 96.3 & 88.9 & 77.8 & 59.3 & 59.3 & not included & 96.3 & 59.3 \\
\hline
\end{tabular}

\section{Summary}

The measurements and calculations of microclimate indexes presented showed that measures taken to ensure the required working conditions remained safe (air conditioning in a longwall) were not effective for all of the longwalls being researched. Keeping the air temperature at the tailgate of longwalls at a required level is very difficult when using the $\mathrm{U}$ ventilation system due to a considerable inflow of heat from goaf.

At the headgate of longwall, thermal working conditions allowed for full-time work, in most cases mainly thanks to an air conditioning system in an intake airway. In about $41 \%$ of the tialgates under research, a temperature of $28^{\circ} \mathrm{C}$ was exceeded or the cooling intensity was below 11 Wet Kata, which means a shortened work time in those excavations.

The analysis of microclimate indexes conducted showed that the French temperature and the equivalent temperature of climate are least restrictive. At a similar level, Polish regulations, American effective temperature climate hazard degrees (1 clo) classify excavations for normal work time. There are differences for high temperatures and high relative air humidity.

Non-acclimatized workers should not be employed for work in hard microclimate conditions. Each time after a holiday or a longer break from work a miner should be gradually acclimatized at a given work place, especially in the case of miners working in a face of longwall or in the tailgates.

The authors are aware that the conclusions above refer to the specific longwalls under research and cannot be generalized for all the work of a longwall. Research should also be conducted over a longer period of time due to the changing character of air parameters during mining a panel of a longwall. It is also essential that workers should be examined with regard to their time exposure to microclimate conditions. In such cases, conclusions could be 
generalized. However, it is necessary carry out research with regard to changing the regulations concerning employment and work organization in environments with very hard microclimate conditions.

\section{Acknowledgements}

The article was prepared as a result of Strategic Project: "Improving safety of work in mines" financed by The National Centre for Research and Development, task 5, contract No. SP/K/5/143275/11. The authors are grateful to JSW Coal Company for enabling all necessary measurements in longwalls to be conducted.

\section{REFERENCES}

[1] SzlązakN., Tor A., Jakubów A.: Metody zwalczania zagrożenia temperaturowego w kopalniach Jastrzębie Coal Company. ROP'2005: zwalczanie zagrożenia cieplnego w kopalniach - teoria i praktyka, 20 października Gliwice 2005, pp. 63-81 (in Polish)

[2] SzlązakN., Tor A.: Wpływ trudnych warunków cieplnych na organizm ludzki. Bezpieczeństwo Pracy i Ochrona Środowiska w Górnictwie, nr 5, 2000, pp. 9-13 (in Polish)

[3] Trutwin W.: W trudnych warunkach cieplnych. Ratownictwo górnicze, nr 4, grudzień 1998, pp. 19-20

[4] Szlazak N., Borowski M., Obracaj D.: Kierunki zmian w systemach przewietrzania ścian eksploatacyjnych z uwagi na zwalczanie zagrożeń wentylacyjnych. Gospodarka surowcami mineralnymi, t. 4, z.1/2, 2008 (in Polish)

[5] Hill L., Griffith O.W., FlackSource M.: Philosophical Transactions of the Royal Society of London. Series B, Containing Papersof a Biological Character, vol. 207, 1916, pp. 183-220

[6] Drenda J.: Dyskomfort cieplny w środowiskach pracy kopalń głębokich. Zeszyty Naukowe Politechniki Śląskiej, seria Górnictwo, z. 213, Gliwice 1993

[7] Turkiewicz W.: Propozycja nowego wskaźnika oceny warunków klimatycznych w kopalniach LegnickoGłogowskiego Okręgu Miedziowego, Cuprum, nr 3-4, 1986, pp. 10-13

[8] PN-EN 27243:2005: Wyznaczanie obciążenia termicznego działającego na człowieka podczas pracy, oparte na wskaźniku WBGT

[9] Rozporządzenie Ministra Gospodarki z dnia 28 czerwca 2002 r. w sprawie bezpieczeństwa i higieny pracy, prowadzenia ruchu oraz specjalistycznego zabezpieczenia przeciwpożarowego w podziemnych zakładach górniczych (Dz. U. Nr 139, poz. 1169 oraz z 2006 r. Nr 124, poz. 863 (Polish laws and regulations)

[10] Fanger, P.O.: Thermal comfort: Analysis and applications in environmental engineering, Copenhagen, Danish Technical Press, 1970

[11] Drenda J.: Wyznaczenie stopni i stref zagrożenia klimatycznego pracowników w przodkach kopalń głębinowych. Przegląd Górniczy, nr 12, 2010, pp. 41-49 